\title{
MINIMAL INHIBITORY CONCENTRATION OF HYGROMYCIN FOR SELECTING TRANSFORMED OIL PALM EMBRYOGENIC CALLI
}

\section{ISKANDAR NOR FAKHRANA*; A RAHMAN NURFAHISZA*; OMAR ABD RASID* and GHULAM KADIR AHMAD PARVEEZ*}

\begin{abstract}
Determination of optimum concentrations for a selection agent is important in obtaining true transformants during the selection stage. In this study, the minimal inhibitory concentrations of hygromycin for four different types of oil palm embryogenic calli (suspension, fine, yellowish and whitish) that were cultured on proliferation, maturation and regeneration media were assessed. The embryogenic calli were cultured on media supplemented with different concentrations of hygromycin. Data on embryogenic callus weight increment was recorded monthly for six months during subculturing. Our results demonstrated that oil palm embryogenic calli cultured on regeneration media (EC) were very sensitive to hygromycin. The growth of embryogenic calli was affected at a relatively low concentration of hygromycin as compared to suspension calli that were cultured on proliferation media (L-1). The regeneration of fine, yellowish and whitish embryogenic calli was completely inhibited at 5-6 mg litre-1 of hygromycin. In contrast, higher concentration of hygromycin at $10 \mathrm{mg} \mathrm{litre}^{-1}$ is needed to inhibit the proliferation of suspension calli cultured on proliferation media. The hygromycin concentrations determined for each of the embryogenic callus types can be used as a guideline to select true transformants in future oil palm transformation works.
\end{abstract}

Keywords: hygromycin selection, oil palm, embryogenic calli.

Date received: 16 March 2018; Sent for revision: 19 March 2018; Received in final form: 13 July 2018 ; Accepted: 18 December 2018.

\section{INTRODUCTION}

Oil palm (Elaeis guineensis Jacq.), a West African origin, has now become a major economic crop in Malaysia and the most efficient yielding oil bearing crop in the world (Kushairi et al., 2017). Being a major economic crop, it is important for it to remain competitive and sustainable. Biotechnology has been identified as a tool to improve the value of oil palm as it could produce high value fatty acids and metabolites

\footnotetext{
Malaysian Palm Oil Board,

6 Persiaran Institusi, Bandar Baru Bangi,

43000 Kajang, Selangor, Malaysia.

E-mail: omar@mpob.gov.my
}

which could not be achieved or required a very long process through conventional plant breeding. Furthermore with the long regeneration period (710 years) of oil palm breeding, biotechnology could effectively reduce the time to genetically improve oil palm (Sambanthamurthi et al., 2009). Biotechnology of oil palm aims at modifying the composition of the fatty acid, especially increasing the oleic acid, stearic acid, palmitoleic acid and ricinoleic acid as well as synthesising novel metabolites such as lycopene (carotenoid) and polyhydroxybutyrate, a biodegradable plastics (Masura et al., 2017; Parveez et al., 2015a). Biotechnological efforts require a genetic transformation system to transfer foreign genes into oil palm. 
Genetic transformation of monocot was started as early as 1980 s by the production of transgenic Asparagus officinalis (Bytebier et al., 1987). Since then, tremendous efforts have been made to transform other monocots including oil palm with useful genes to enhance the plant quantitative traits. Those plants were usually transformed either using particle bombardment or Agrobacterium-mediated transformation. The method to transform oil palm via particle bombardment and Agrobacteriummediate gene transfer was developed by Parveez and Christou (1998) and Masli et al. (2009), respectively. Both techniques are routinely used to incorporate different genes of interest into oil palm target tissue. Bombardment technique was successfully used to transform polyhydroxybutyrate (Parveez et al., 2008; 2015b; Yunus et al., 2008), herbicide Basta or glufosinate ammonium resistant (Parveez et al., 2000; Yunus and Kadir, 2008), phosphomannose isomerase (PMI) (Bahariah et al., 2013), and green fluorescent protein (Majid and Parveez, 2007; 2016; Parveez and Majid, 2008) into oil palm tissues. Meanwhile, 2-deoxyglucose-6-phosphate phosphatase (DOG ${ }^{\mathrm{R}} 1$ ) (Izawati et al., 2015) and bar genes (Masli et al., 2009) were transformed via Agrobacterium-mediated gene transfer technique. Prior to the transformation of the desired genes, preliminary experiments are often conducted to determine minimal inhibitory concentration (MIC) of selection agent required for efficient selection under established culture condition. For oil palm, a number of MIC studies have been done using different types of selection agents such as kanamycin, geneticin G-418, neomycin, hygromycin, herbicide Basta, phosphomannose isomerase, DOG 1 , bialaphos and glufosinate ammonium (Parveez et al., 2007; Bahariah et al., 2012; Masli et al., 2012; Nurfahisza et al., 2016). Based on the MIC result, the putatively transformed tissues will be selected and regenerated on the specific concentration of the desired selection agent.

At present, Basta selection has been frequently used in oil palm transformation studies. As reported in previous oil palm transformation works using Basta as selection agent, about $1 \%$ $1.5 \%$ and $0.7 \%$ of transformation efficiency was obtained via particle bombardment (Parveez et al., 2000) and Agrobacterium-mediated transformation (Masli et al., 2009), respectively. Even though the transformation efficiencies obtained from both oil palm transformation techniques are acceptable for recalcitrant plant species, the oil palm transformation efficiency is still low compared to other monocots (Izawati et al., 2015; Parveez et al., 2015a). The low transformation efficiency is often associated with the presence of false positive or escapes plants. Generation of escapes or chimeras during selection and regeneration of transformed tissues cultured on culture media containing a selection agent is a major problem in most transformation systems (Miki and McHugh, 2004).

The type of selection agent, optimum concentration of selection agent and optimum period of selection phase are all the prerequisites that must be known for efficiently selecting true transformants. Usually, only minor parts of the target tissues are transformed, while the vast majority remains nontransformed. The chances to recover the transgenic lines without selection are usually low. Thus, it is necessary to determine the optimum parameters for selection as a less stringent selection could result in the regeneration of escapes (d'Erfurth et al., 2003; Gutierrez et al., 1997). The problem of escapes has been reported in early transformation works in rice (Christou and Ford, 1995), sorghum (Casas et al., 1997), tobacco (Park et al., 1998) and wheat (Altpeter et al., 1996). Similar problem has also been reported in oil palm transformation suggesting the escapes phenomenon in oil palm could be due to the use of low concentration of herbicide Basta during selection (Nurfahisza et al., 2014). Recently, Itaya et al. (2018) reported that regeneration of escapes transgenic soyabean plants could be eliminated through prolonged selection on hygromycin selection medium.

In this study, we evaluated hygromycin as an alternative to the Basta selection. Hygromycin is the second most widely used selection agent in plant transformation study (Miki and McHugh, 2004). It inhibits protein synthesis by causing mistranslation and interferes with protein translocation (Gonzalez et al., 1978). Hygromycin has been commonly used in monocot transformation such as rice (Htweet al., 2014; Shimamoto et al., 1989) and wheat (Raja et al., 2010). In a previous study on oil palm, hygromycin at $20 \mathrm{mg}$ litre $^{-1}$ was identified as minimal inhibitory concentration for completely prevented the growth of immature embryos (Abdullah et al., 2005; Parveez et al., 2007). Parveez et al. (2007) mentioned that, as early as five weeks of culture on $20 \mathrm{mg}$ litre $^{-1}$ of Basta and hygromycin was effective to completely kill immature embryo and they are the most suitable selection agents to be applied when immature embryos is used as target tissue compared to kanamycin, paromomycin and geneticin G418. However, information on the optimal hygromycin concentration for selecting oil palm transformants derived from different tissues and developmental stages has not been reported.

The aim of this study is to determine the MIC of hygromycin for selecting transformed oil palm embryogenic calli at different stages of culture such as suspension, fine, yellowish or whitish calli. Suspension and fine calli are normally used as target tissues for oil palm transformation (Parveez et al., 2008; 2015b; Masli et al., 2009; Bahariah et al., 2013; Izawati et al., 2015). Meanwhile, the yellowish and whitish calli represent slightly advance developing 
stages of the embryogenic calli during tissue culture. The concentration of hygromycin depends largely on genotype, type of explants, explant sizes and even within different stages of development of the same species (Milojević et al., 2012). Therefore, it is important to determine the MIC for each tissue culture stage to tighten the selection process. This outcome is critical to eliminate the possibility of obtaining escape and chimeric plant. The information gained from this study will improve the selection process in oil palm transformation work to successfully select and regenerate true transformants.

\section{MATERIALS AND METHODS}

\section{Preparation of Culture Media}

In this study, callus proliferation (L-1), callus maturation (MSB) and callus regeneration (EC) media were used. The composition of these media is listed in Table 1. Hygromycin (Sigma) was supplied as sterile-filtered solution in $50 \mathrm{mg} \mathrm{ml}^{-1}$ stock and it was added directly to the media. The media were autoclaved at $121^{\circ} \mathrm{C}$ for $15 \mathrm{~min}$ and cooled down to $50^{\circ} \mathrm{C}$ before hygromycin was added to the needed concentrations.

\section{Preparation of Plant Materials}

Plant materials were obtained from Clonal Propagation Group, MPOB. Embryogenic calli established from tenera oil palm cabbage were used as the starting material. The embryogenic calli consist of suspension, fine, yellowish and whitish calli. The first part of the experiment was carried out to determine the minimal hygromycin concentration that inhibits proliferation of suspension (immature) calli cultured on proliferation media, L-1. The suspension calli aged 8-month old were obtained from liquid culture (Figure 1A). The suspension calli were filtered from L-1 liquid culture medium using $300 \mathrm{~mm}$ stainless steel mesh. The filtered calli (0.5 g) were cultured on L-1 solid media containing various concentrations of hygromycin $(0,2,4,6,8$ and $10 \mathrm{mg}$ litre $\left.{ }^{-1}\right)$ and incubated in the dark at $28^{\circ} \mathrm{C}$.

The second part of experiments was conducted to determine the optimum hygromycin concentration that inhibits regeneration of fine, yellowish and whitish calli (collectively named as mature calli) on regeneration media, EC. Fine calli refers to the suspension calli that were previously cultured in maturation liquid media (MSB) for a month and then freshly transferred on EC solid media (Figure 1B). While, the yellowish and whitish calli were derived from fine calli that were cultured for a month on EC

\section{TABLE 1. LIST OF CULTURE MEDIA USED IN THIS STUDY}

\begin{tabular}{|c|c|}
\hline Media & Composition \\
\hline L-1 & 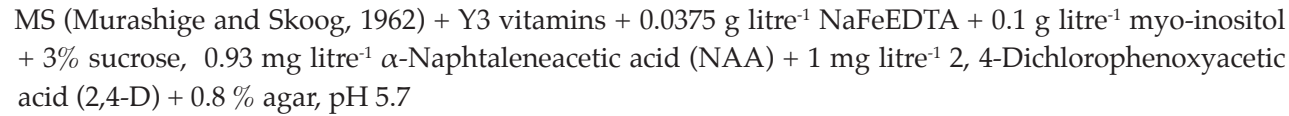 \\
\hline EC & L-1 media without $2,4-\mathrm{D}$ \\
\hline MSB & MS basal media \\
\hline
\end{tabular}

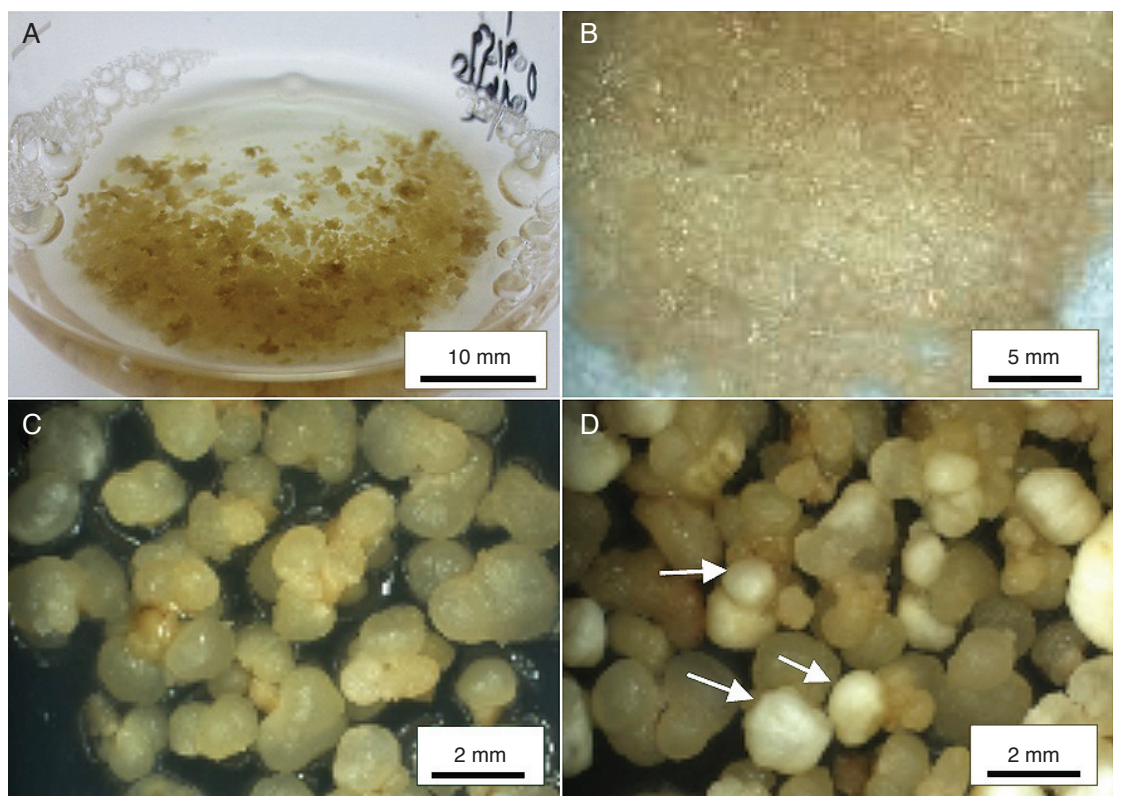

Figure 1. Types of oil palm calli used in this study. A: suspension calli; B: fine calli; C: yellowish calli; D: whitish calli (arrow). 
media (Figures 1C to $1 D$ ). Those embryogenic calli were cultured on EC solid media supplemented with different concentrations of hygromycin $(0,1,2,3,4$, $5,6,7,8,9$ and $10 \mathrm{mg}$ litre $^{-1}$ ). Approximately $0.5 \mathrm{~g}$ of embryogenic calli was cultured on each plate and the plates were incubated for $16 \mathrm{hr}$ photoperiod at $28^{\circ} \mathrm{C}$. Each treatment was conducted in five replicates. The embryogenic calli were subcultured every fourweek interval onto fresh media containing the same concentration of hygromycin for six months.

\section{Measurement of Proliferation Rate}

Callus development on media added with different hygromycin concentrations was compared to the control (embryogenic calli on hygromycinfree media). Weight increment of embryogenic calli cultured on different concentrations of hygromycin was measured and recorded at a monthly interval. Callus proliferation rate was calculated as the percentage of weight increment using the following equation:

$\underset{\text { proliferation rate }}{\text { Callus }}=\left(\frac{\mathrm{cwHx}, \mathrm{m} 1-\mathrm{CwHx}, \mathrm{m} 0}{\mathrm{cwH} 0, \mathrm{~m} 1-\mathrm{CwH} 0, \mathrm{~m} 0}\right) \times 100 \%$

where:

$\mathrm{CwHx}$ - weight of embryogenic calli cultured on hygromycin-media.

$\mathrm{CwH} 0$ - weight of embryogenic calli cultured on hygromycin free-media.

m1 - in current month

m0 - in previous month

The control treatment was defined as $100 \%$ growth in a particular data set, assuming that there was no inhibitory element affecting the callus proliferation (Parveez et al., 1996). The optimal concentration of hygromycin was determined based on the concentration of hygromycin that completely inhibited the proliferation and regeneration of untransformed embryogenic calli.

\section{Statistical Analysis}

All data were statistically tested by analysis of variance (ANOVA) using SPSS software. The least significant differences at $\mathrm{p} \leq 0.05$ indicated treatment effect was significant.

\section{Histological Analysis}

Histological analysis was carried out for each developmental stage of embryogenic calli according to Fisher (1968) and Mari et al. (1995) with minor modifications. The embryogenic calli were fixed in glutaraldehyde-paraformaldehyde-caffeine (GPC) fixative buffer $[50 \mathrm{ml} 0.2 \mathrm{M}$ phosphate buffer, $\mathrm{pH}$ 7.2; $20 \mathrm{ml} \mathrm{10 \%}$ paraformaldehyde; $4 \mathrm{ml} \mathrm{25 \%}$ glutaraldehyde (Sigma G-6257); $1 \mathrm{~g}$ caffeine; $26 \mathrm{ml}$ distilled water] for 24 to $48 \mathrm{hr}$ at room temperature. The samples were then dehydrated in ascending ethanol percentage: $30 \%$ (30 $\mathrm{min}$ ); 50\% (45 min); $70 \%$ (45 min); $80 \%$ (60 min); $90 \%$ (60 min); 95\% (60 $\mathrm{min}$ ) and twice in absolute ethanol for 60 min each. The samples were further bathed in butanol three times for a minimum of $24 \mathrm{hr}$ per bath, and then in impregnation-butanol solution for a minimum of $48 \mathrm{hr}$. The tissues were then prepared for filtration with basic resin (Leica Historesin Embedding Kit) for $24 \mathrm{hr}$ at $4^{\circ} \mathrm{C}$ under slight vacuum. The specimens were embedded in impregnation-hardener II solution, where the samples were left to dry in the mold overnight. The resin was allowed to be fully polymerised after which holders were attached and $5 \mu \mathrm{m}$ sections were sliced using a Leica microtome (Leica, Germany). Slides were stained in Periodic acid-Schiff reagent for $20 \mathrm{~min}$ and Naphthol blue black at $60^{\circ} \mathrm{C}$ for $5 \mathrm{~min}$. Distilled water, $\mathrm{pH} 4.5$ was applied in between staining steps to wash off excess dye. The Periodic acid-Schiff (red stain) specifically stains polysaccharide (starch reserves and walls) while Naphthol blue-black specifically stains soluble or reserve proteins in blue-black (Fisher, 1968). Images of the slides were viewed and photographed with a camera attached to AZ100 microscope (NIKON).

\section{RESULTS AND DISCUSSION}

\section{Preliminary Study}

An initial experiment was carried out to test hygromycin concentrations ranging from 10-100 $\mathrm{mg}$ litre $^{-1}$ using untransformed fine, yellowish and whitish calli. The experiment was conducted up to six months on the same selection agent containing medium. It was discovered that all the callus growth was fully inhibited even at the lowest concentration of hygromycin tested, $10 \mathrm{mg}$ litre $^{-1}$ (Figure 2). Hygromycin at $10 \mathrm{mg}$ litre $^{-1}$ could be too high as it could negatively affect the embryogenic callus development. The use of a very high concentration of selection agent would be too stringent which may result in the failure of moderately resistant calli to survive and regenerate (Ijaz et al., 2012). Therefore, a further study was conducted to determine the optimum concentration of hygromycin on oil palm callus types by focusing on concentration between 1-10 mg litre ${ }^{-1}$.

\section{Determination of Hygromycin Concentration using Suspension Calli}

The L-1 callus culture is the first stage of oil palm regeneration via embryogenic calli. It is crucial to determine the MIC at this stage, when 

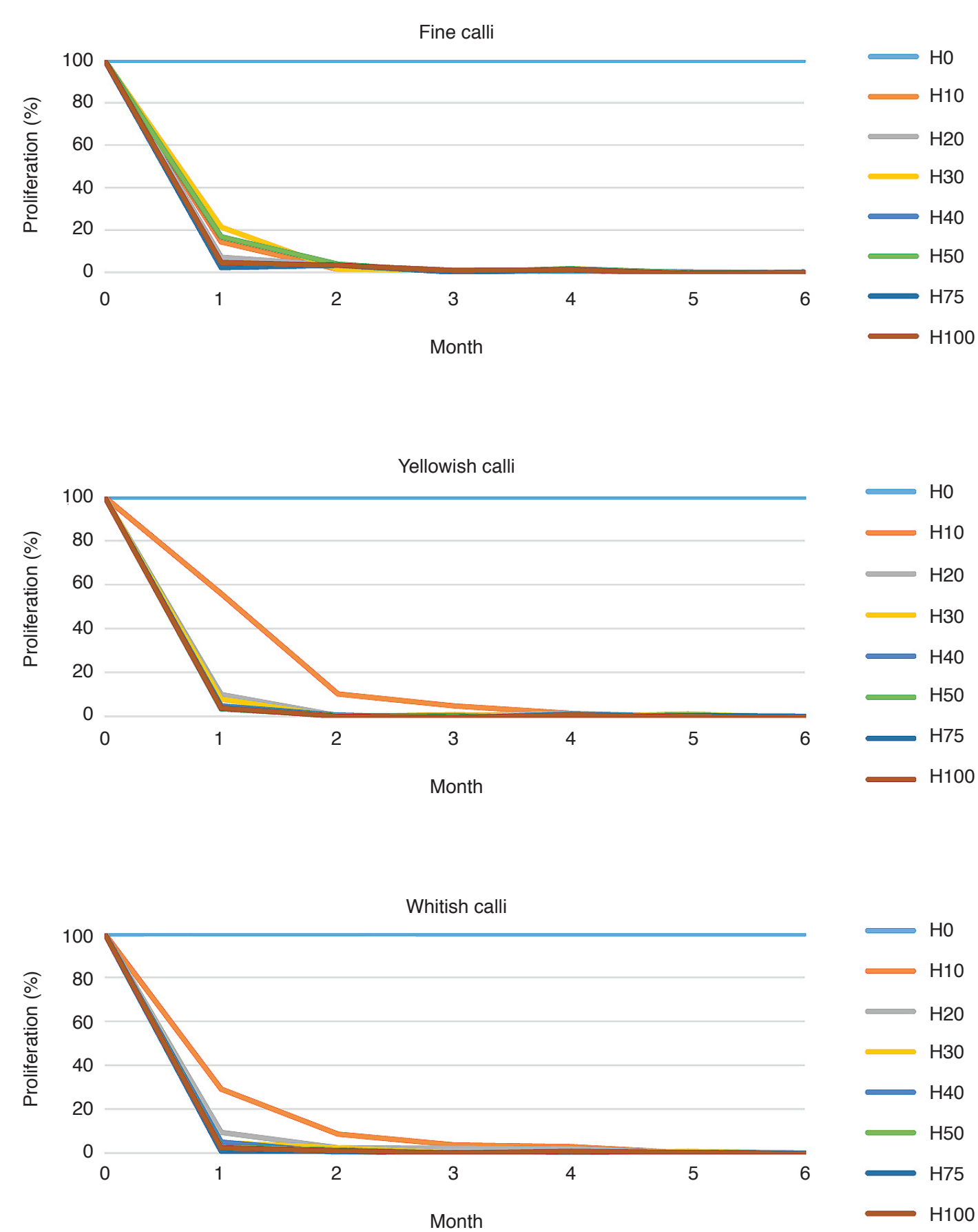

Figure 2. Preliminary minimal inhibitory concentration (MIC) experiments were performed using untransformed fine, yellowish and whitish calli cultured on 10-100 mg litre-1 of hygromycin up to six months.

the suspension calli are used as a target tissue. An accurate determination of MIC at the early stage would also prevent unnecessary tissue culture procedures during regeneration of transformants by eliminating untransformed tissues at the proliferation stage. Determination of MIC for suspension calli was entirely based on the weight increment, since the embryogenic calli were continuously cultured on callus proliferation media. Hygromycin at the concentrations of 2-8 mg litre ${ }^{-1}$ was insufficient to fully inhibit the proliferation of suspension calli. The suspension calli were shown to continue to proliferate at $90.3 \%, 68.6 \%, 50.8 \%$ and $24.2 \%$, at the concentrations of 2, 4, 6 and $8 \mathrm{mg} \mathrm{litre}^{-1}$, respectively (Figure 3). The embryogenic calli were shown to continue to increase in weight, even at the sixth month of culture. However, the proliferation of suspension calli was completely stunted when cultured on the media containing $10 \mathrm{mg}$ litre $\mathrm{l}^{-1}$ of hygromycin, at the sixth month of culture. On 10 mg litre ${ }^{-1}$ of hygromycin, the tissue turned brownish (Figure 4F) and exhibited decreased cell growth 


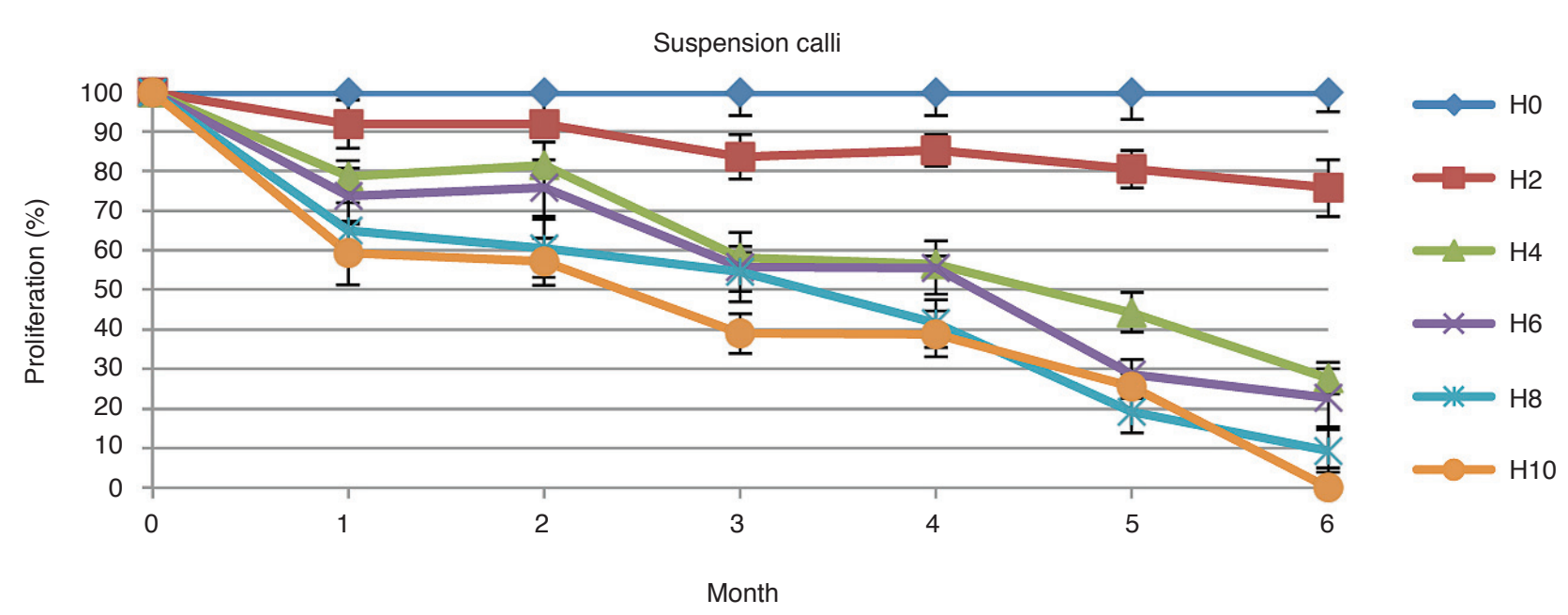

Figure 3. Proliferation percentage of suspension calli being cultured onto L-1 media containing different concentrations of hygromycin up to six months. H0: control without hygromycin; H2: 2; H4: 4; H6: 6; H8: 8 and H10: 10 mg litre-1 hygromycin. The bars indicate \pm standard errors.

indicated by the smallest cell aggregates compared to cultures on lower concentrations of hygromycin (Figures $4 B$ to $4 E$ ). In contrast, the suspension calli cultured on media without hygromycin were yellowish and developed into bigger embryogenic masses (Figure 4A).

\section{Determination of Hygromycin Concentration using Mature Calli}

The suspension calli proliferated on maturation media (MSB) which later developed into yellowish and whitish calli when cultured on the EC media. Therefore, the MIC for each type of calli should be determined in order to efficiently eliminate untransformed tissues at every stage of callus development. Based on the plotted curves in Figure 5, it was clearly seen that 1 and $2 \mathrm{mg} \mathrm{litre}^{-1}$ of hygromycin were not effective in preventing callus proliferation in all types of embryogenic calli. For instance, the fine calli could still proliferate up to $96.85 \%$ and $91.19 \%$ on 1 and 2 mg litre ${ }^{-1}$ of hygromycin, respectively (Figure 5A). The proliferation of all mature embryogenic calli started to decline on media containing $3 \mathrm{mg}$ litre $^{-1}$ and onwards. As the concentration increased, the proliferation rate was decreased and finally inhibited. Hygromycin at 6 $\mathrm{mg}$ litre ${ }^{-1}$ was detrimental for fine calli (Figure $5 A$ ).
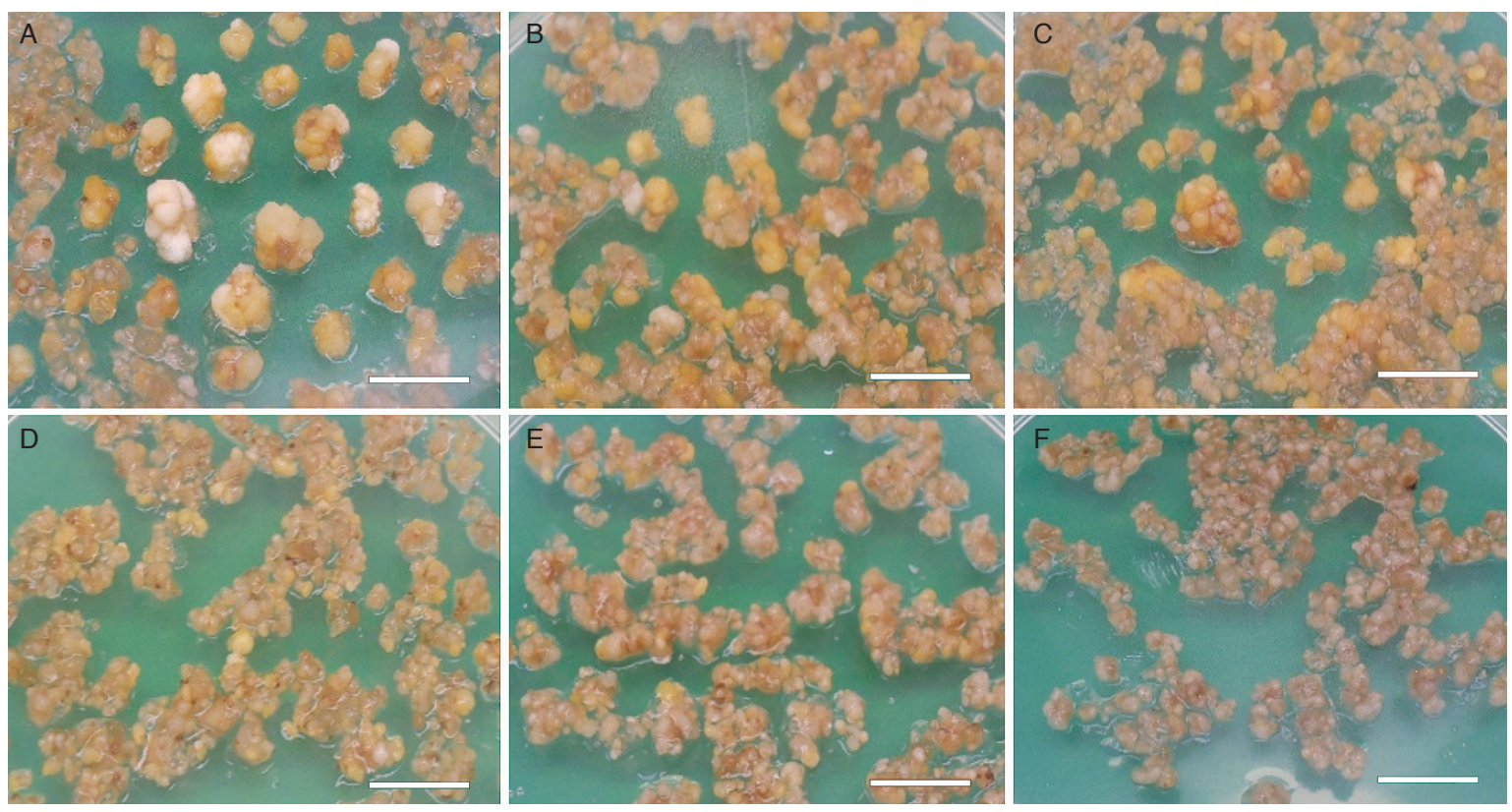

Figure 4. Proliferation of suspension calli after being cultured for six months on L-1 media containing 0-10 mg litre-1 hygromycin. A: Control without hygromycin; B: 2; C: 4; D: 6; E: 8 and F: $10 \mathrm{mg}$ litre-1 hygromycin. At no and low concentration of hygromycin, the calli developed faster compared to the calli cultured on higher concentration of hygromycin as indicated by their bigger size (scale bar indicates $10 \mathrm{~mm}$ ). 

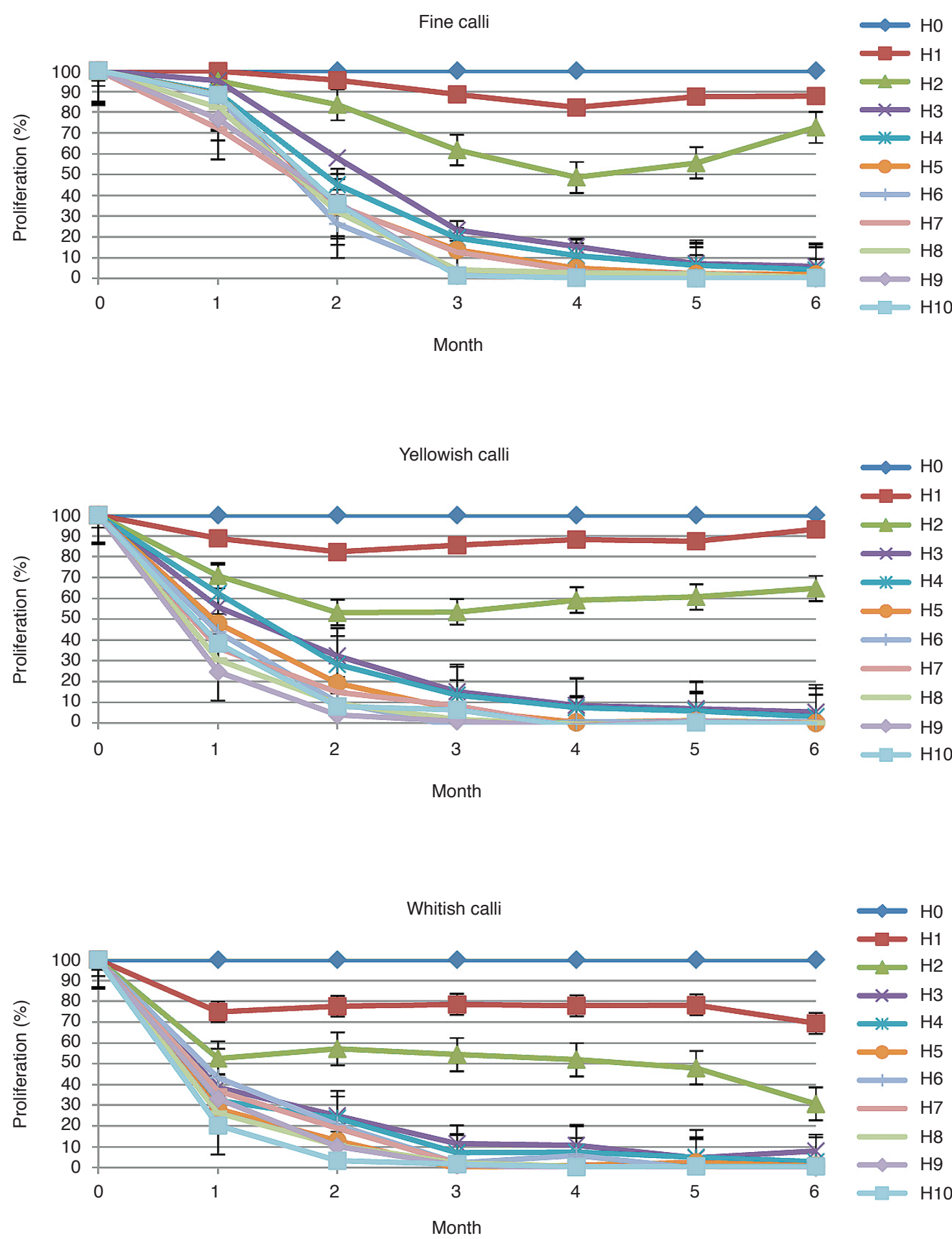

Figure 5. Proliferation percentage of embryogenic calli after being cultured for six months on callus regeneration (EC) media containing different concentrations of hygromycin. A: Fine calli; B: yellowish calli; C: whitish calli. H0: control without hygromycin; H1: 1 ; H2: 2; H3: 3; H4: 4; H5: 5; H6: 6; H7: 7; H8: 8; H9: 9 \& H10: $10 \mathrm{mg}$ litre-1 hygromycin. The proliferation percentage for the three types of calli cultured on EC media was significantly affected by the different concentrations of hygromycin tested ( $p<0.05$ ).

Whilst, yellowish (Figure 5B) and whitish calli (Figure $5 C$ ) were fully inhibited on $5 \mathrm{mg}$ litre $^{-1}$ of hygromycin. Effects of hygromycin on the development of the three types of embryogenic calli for six months on EC media supplemented with different concentrations of hygromycin embryogenic calli are as shown in Figures 6 to 8 .

\section{Comparison of MIC between Immature and Mature Calli}

Higher hygromycin concentration (10 mg litre $^{-1}$ ) was needed to inhibit the proliferation of suspension calli compared to fine calli $\left(6 \mathrm{mg} \mathrm{litre}^{-1}\right)$, as well as yellowish and whitish calli (5 mg litre ${ }^{-1}$ ). 

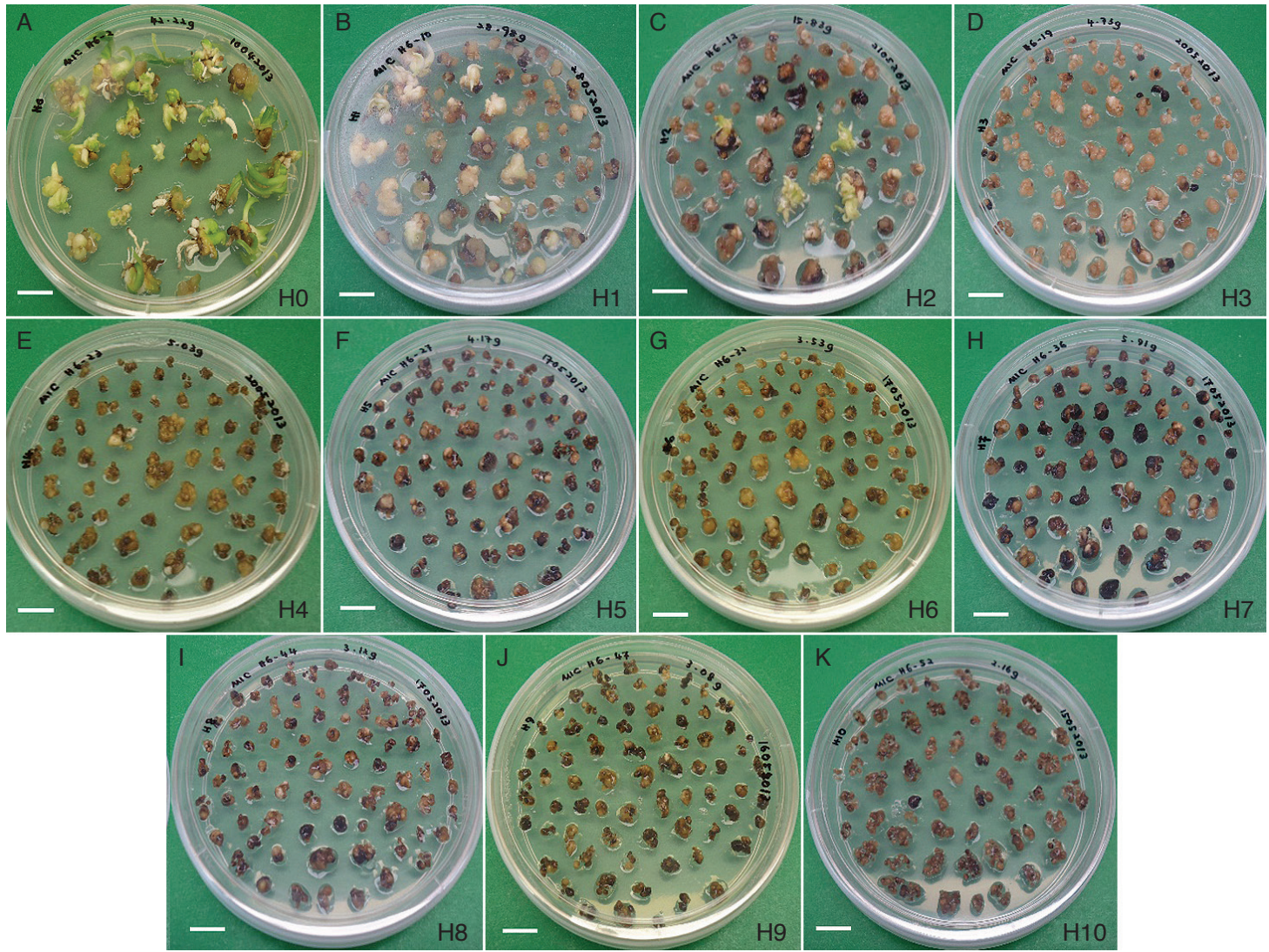

Figure 6. Development of fine calli after being cultured for six months on callus regeneration (EC) media supplemented with different concentrations of hygromycin. A: Control without hygromycin ; B: 1; C: 2; D:3; E: 4; F: 5; G: 6; H: 7; I: 8; J: 9 and K: 10 mg litre li $^{-1}$ gromycin (scale bar indicates 10 mm).
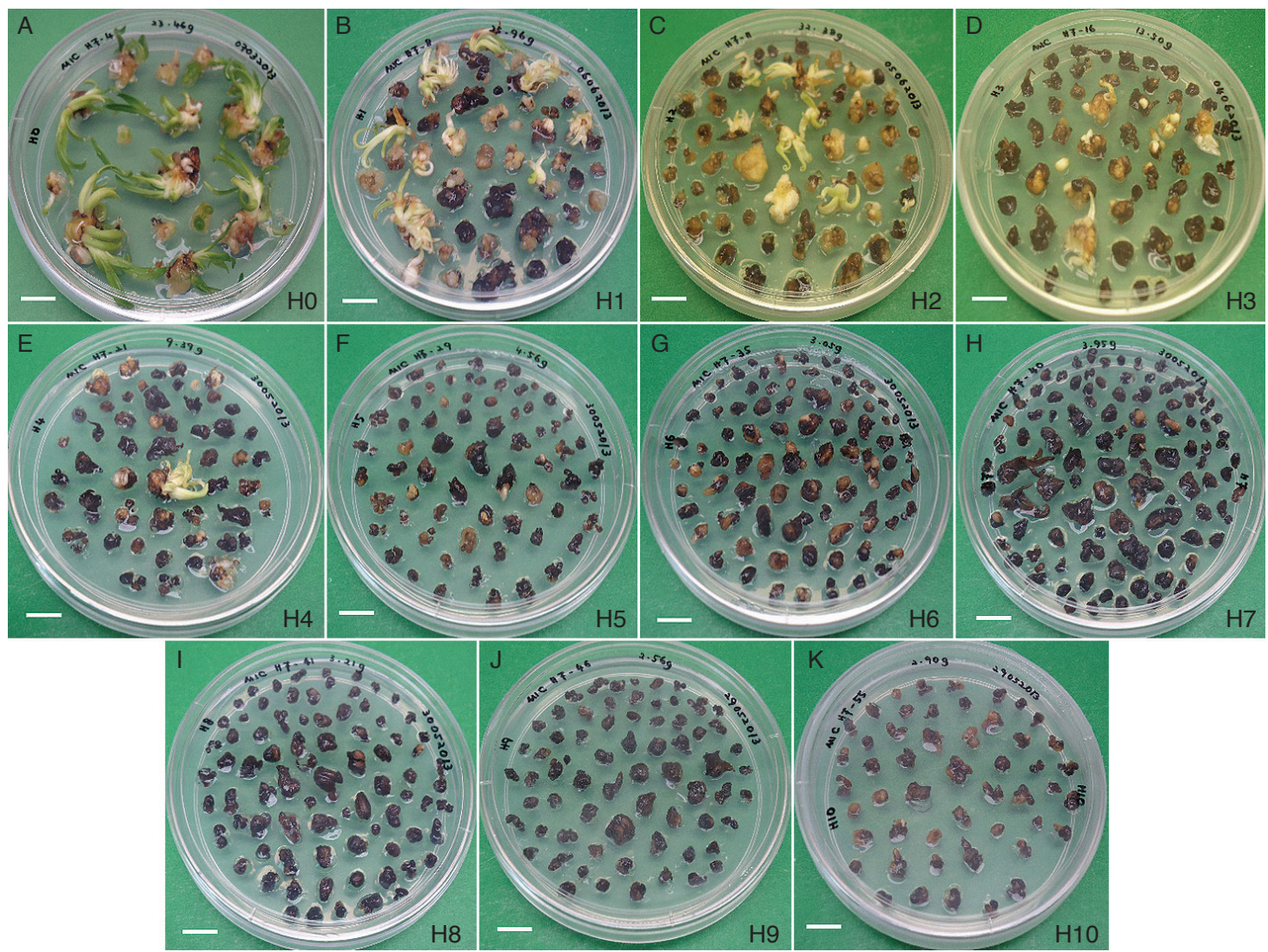

Figure 7. Development of yellowish calli after being cultured for six months on callus regeneration (EC) media supplemented with different concentrations of hygromycin. A: Control without hygromycin; B: 1; C: 2; D: 3; E: 4; F: 5; G: 6; H: 7; I: 8; J: 9 and K: 10 mg litre hygromycin $^{-1}$ (scale bar indicates $10 \mathrm{~mm}$ ). 


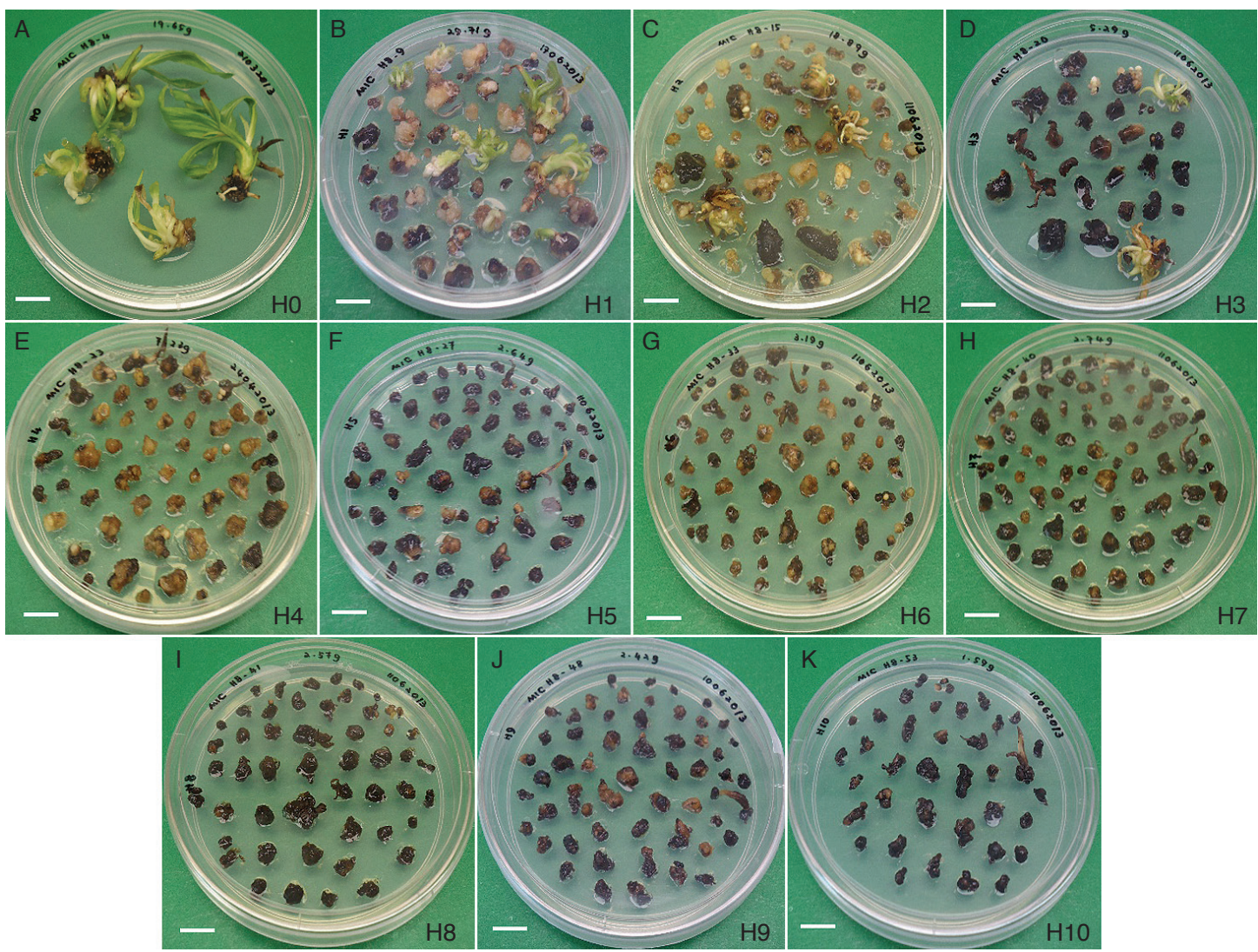

Figure 8. Development of whitish calli after being cultured for six months on callus regeneration (EC) media supplemented with different concentrations of hygromycin. A: Control without hygromycin; B: 1; C: 2; D: 3; E: 4; F: 5; G: 6; H: 7; I: 8; J: 9 and K: 10 mg litre-1 hygromycin (scale bar indicates $10 \mathrm{~mm}$ ).

One possible reason for the different sensitivity between immature and mature embryogenic calli towards hygromycin was due to the different types of media used, which can lead to the differences in callus anatomy. The suspension and mature embryogenic calli were cultured on callus proliferation (L-1) and EC, respectively. The suspension calli are actively dividing cell cultures on the L-1 media which contain plant growth regulator 2, 4-Dichlorophenoxyacetic acid (2, 4-D). At this stage, oil palm suspension callus aggregates consist of round and actively dividing cells based on the histology analysis done by Teixeira et al. (1995). Previous studies have shown that 2, 4-D plays an important role in the dedifferentiation and cell division in somatic embryogenesis (Constantin et al., 2015; Meneses et al., 2005; Sané et al., 2006).

According to the analysis of variance, there were significant differences in the callus weight increment data obtained from the different hygromycin concentrations and types of embryogenic calli used (Table 2). Fluctuation of hygromycin even at $1 \mathrm{mg} \mathrm{litre}^{-1}$ has brought a lot of differences to the proliferation rates. Significant reduction on the growth rate was seen on $3 \mathrm{mg}$ litre $^{-1}(\mathrm{H} 3)$ and above. Approximately $50 \%$ reduction in the proliferation rate were recorded for $\mathrm{H} 3$ compared to the $\mathrm{H} 2$ treatment. Oil palm embryogenic calli can be considered as highly sensitive to the hygromycin since the regeneration of embryogenic calli was

TABLE 2. ANOVA OF HYGROMYCIN CONCENTRATION AND TYPE OF EMBRYOGENIC CALLI ON THE PROLIFERATION OF EMBRYOGENIC CALLI

\begin{tabular}{lccc}
\hline \multicolumn{1}{c}{ Treatment } & \multicolumn{3}{c}{ Variance of proliferation rate (\%) } \\
\cline { 2 - 4 } & Mean square & F value & Sig. \\
\hline Hygromycin concentration & 23018.953 & 72.947 & $0.000^{*}$ \\
Type of embryogenic calli & 6922.631 & 21.938 & $0.000^{*}$ \\
\hline
\end{tabular}

Note: ${ }^{*}$ The proliferation rate was significantly affected by the different concentrations of hygromycin and types of embryogenic calli tested $(\mathrm{p}<0.05)$.

ANOVA - analysis of variance. 
inhibited at as low as $5 \mathrm{mg}$ litre $^{-1}$ of hygromycin. The use of low hygromycin concentration $\left(5 \mathrm{mg} \mathrm{litre}^{-1}\right)$ was reported in other plants such as Oncidium orchid (Ong et al., 2000; Liau et al., 2003) and Jatropha curcas (Li et al., 2008). Differential sensitivity towards hygromycin could be due to the variation of plant species and explants used such as single buds of banana at $20 \mathrm{mg}$ litre $^{-1}$ (Sreeramanan et al., 2006), immature embryo of barley at $50 \mathrm{mg}$ litre $^{-1}$ (Bartlett et al., 2008), immature embryos and embryogenic calli of rice at $30-50 \mathrm{mg}$ litre-1 of hygromycin (Li et al., 1993).

Amongst the three types of mature embryogenic calli, fine calli were the least sensitive to hygromycin as compared to yellowish and whitish calli. The difference in response towards hygromycin is not known. Therefore, histology analysis of the all the four types of embryogenic calli was carried out to compare the nature of the embryogenic callus types and hopes to find the answer for the different level of sensitivity to hygromycin. Histological observation clearly indicated that there were differences in the anatomy between mature and immature embryogenic calli and also between mature embryogenic calli itself, as shown in Figure 9.

Suspension calli consist of globular and typically small cells with a dense cytoplasm, a nucleus with an evident nucleolus and a high nucleus / cytoplasm ratio (Figures $8 A$ to $8 B$ ). A high ratio of nucleus/ cytoplasm indicated the presence of meristematic zones that could lead to the development of somatic embryos and the formation of shoots. The result obtained agrees with the morphological characteristics of somatic embryos from sugar cane (Alcantara et al., 2014), Pelargonium (Haensch, 2007) and date palm (Sané et al., 2006). When the suspension calli were transferred to the media devoid of 2, 4-D, they were differentiated and channelled to embryogenesis development. The embryogenic calli started to divide and develop into pro-embryos and globular embryos as seen in the fine callus stage (Figures 9C to 9D). Later, more advanced stage of somatic embryo development was observed. At yellowish callus stage, the formation of heart shape was observed (Figures $9 E$ to $9 F$ ). Whilst, formation of vascular tissues, vascular bundle and apical meristem was clearly identified at the whitish calli stage (Figures 9G to 9J). Indeed, the histological analysis showed that more advanced stage of development was observed in the yellowish and whitish calli compared to the fine calli. The presence of vascular system might assist the transportation and uptake of hygromycin more efficiently to other parts of the tissue, thereby making the whitish calli more sensitive to the added hygromycin compared to the fine calli. This could also answer the reason for obvious toxicity effect observed in whitish calli (Figure 8) compared to immature calli (Figure 4). The findings of histology along with the generated MIC data showed that the concentration of hygromycin needs to be gradually decreased throughout callus maturation process, to ensure that the transformed cells retain the ability to regenerate to normal plants. This could answer the lower concentration needed to completely inhibit the regeneration of yellowish and whitish calli compared to the fine calli.

We noticed that oil palm needs different concentrations of hygromycin when the selection was applied throughout the period of cultivation. A higher concentration of hygromycin, $10 \mathrm{mg}$ litre ${ }^{-1}$ was needed at the callusing stage and once the calli have entered maturation stage, the concentration needs to be reduced to 5-6 mg litre $^{-1}$. Similar observation was reported for Setaria viridis, where 40 $\mathrm{mg}$ litre $^{-1}$ of hygromycin was needed in the callusing media and then reduced to $15 \mathrm{mg}$ litre $^{-1}$ in plant regeneration media (Van Eck et al., 2017). In wheat transformation, hygromycin at $150 \mathrm{mg} \mathrm{litre}^{-1}$ was applied during callus selection and then reduced to $50 \mathrm{mg} \mathrm{litre}^{-1}$ at later selection stage (Gils, 2017). This type of selection is also known as stepwise selection.

The application of stepwise selection, either as gradually increasing or gradually decreasing of hygromycin concentration during the selection period has been reported in some other plant species such as wheat (Mitić et al., 2014) and Aloe vera (Velcheva et al., 2010) to avoid the negative effect of high antibiotic concentration on shoot regeneration and to increase the selection efficiency. Combination of delayed and stepwise increasing of hygromycin selection significantly enhanced the transformation efficiency in wheat by $7 \%$ compared to previously achieved $0.41 \%$ (Mitić et al., 2004). In contrast, Li et al. (2013) demonstrated that for Crambe abyssinica, using a constant low concentration of selection agent or gradually decreasing the selection agent concentration does not influence the transformation efficiency obtained. The results from this study suggest that gradually decreasing the hygromycin selection should be applied in future oil palm transformation study when immature calli are used as the starting material.

Another parameter that should be considered in developing an efficient selection strategy is the optimum duration of selection phase. In this study, it shows that around six months are required to completely inhibit the growth of all the four types of embryogenic calli. In earlier oil palm transformation works, resistant bombarded callus appeared after around five to six months on hygromycin-containing media (Parveez and Christou, 1998). A similar response was observed in rice transformation (Li et al., 1997). They noticed that the fast-growing callus line could be distinguished among the bombarded embryogenic calli after three to four subcultures on selection media containing $30-50 \mathrm{mg}$ litre ${ }^{-1}$ of hygromycin. Whilst, six to eight months of selection on hygromycin were sufficient to allow the regeneration of transformed Alstroemeria 


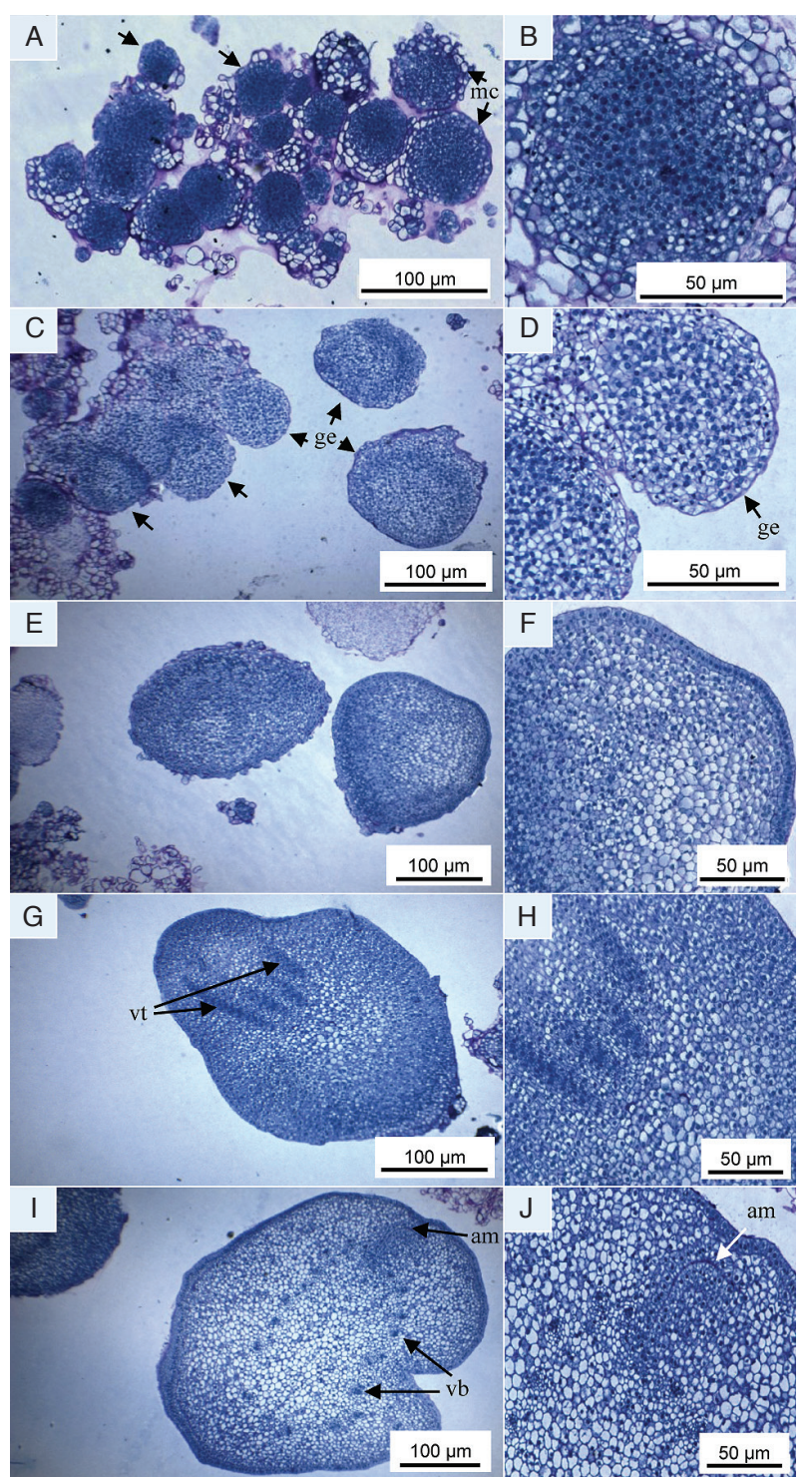

Figure 9. Histological observation of suspension, fine, yellowish and whitish calli. A-B: Suspension calli were made up of meristematic cells $(m c)$; C-D: formation of pro-embryos and globular embryos (ge) were observed in fine calli; E-F: formation of heart shape in yellowish calli; G-J: formation of well-differentiated vascular tissues (vt), vascular bundle $(v b)$ and apical meristem (am) observed in whitish calli.

embryogenic calli (Kim et al., 2007). Whereas, shorter culture period, about five weeks on a super-lethal dose of hygromycin, $200 \mathrm{mg}$ litre $^{-1}$ was sufficient to clearly identify hygromycin resistant of Russian wild rye (Wang et al., 2004).

\section{CONCLUSION}

Our result demonstrated that a higher concentration of hygromycin was needed to inhibit the proliferation of suspension calli compared to mature embryogenic calli. The mature embryogenic calli are very sensitive to hygromycin, since their proliferation and regeneration were inhibited at a relatively low concentration of hygromycin. Thus, to effectively select and regenerate the transformed oil palm embryogenic calli, the concentration of selection agent used during the selection should depend on the types of embryogenic calli used. Therefore, for oil palm transformation using suspension calli as target tissue, early stages of selection need to be carried out at a higher hygromycin concentration, 10 mg litre ${ }^{-1}$ and once the embryogenic calli mature to fine and whitish or yellowish, lower concentrations of hygromycin, 5-6 mg litre ${ }^{-1}$ will need to be applied for an efficient selection of transformants. This is the first report on the evaluation of the effects of hygromycin on different types of oil palm embryogenic calli and could be used as a guideline for the selection of transformants.

\section{ACKNOWLEDGEMENT}

The authors would like to thank the DirectorGeneral of MPOB for permission to publish this article. We wish to thank the Clonal Propagation Group, MPOB for providing the plant materials; Siti Marlia Silong for helping in the technical aspects and data collection; Rosna Angsor from Biomarker Discovery Group, MPOB for her assistance with the histological analysis and Noorizan Baharum from Breeding and Quantitative Genetics Group, MPOB for assisting with statistical analyses. Special thanks to Dr Abdul Masani Mat Yunus and Dr Abrizah Othman for critically reviewing the manuscript. Finally, thanks to the staff of Transgenic Technology Group, MPOB for their kind assistance.

\section{REFERENCES}

Abdullah, R; Zainal, A; Heng, W Y; Li, L C; Beng, Y C; Phing, L M; Sirajuddin, S A; Ping, W Y S; Joseph, J L and Jusoh, S A (2005). Immature embryo: A useful tool for oil palm (Elaeis guineensis Jacq.) genetic transformation studies. Electronic J. Biotechnol., 8(1): 24-34.

Alcantara, G B D; Dibax, R; Oliveira, R A D; Bespalhok Filho, J C and Daros, E (2014). Plant regeneration and histological study of the somatic embryogenesis of sugarcane (Saccharum spp.) cultivars RB855156 and RB72454. Acta Sci-Agron., 36 (1): 63-72.

Altpeter, F; Vasil, V; Srivastava, V; Stoger, E and Vasil, I K (1996). Accelerated production of transgenic wheat (Triticum aestivum L.) plants. Plant Cell Rep., 16: 12-17.

Bahariah, B; Parveez, G K A and Khalid, N (2012). Determination of optimal concentration of mannose as a selection agent for selecting transformed oil palm cells using the phosphomannose isomerase 
(pmi) gene as the positive selectable marker. J. Oil Palm Res. Vol. 24: 1250-1259.

Bahariah, B; Parveez, G K A; Masani, M Y A; Masura, S S; Khalid, N and Othman, R Y (2013). Biolistic transformation of oil palm using the phosphomannose isomerase (pmi) gene as a positive selectable marker. Biocatal. Agri. Biotech., 2(4): 295304.

Bartlett, J G; Alves, S C; Smedley, M; Snape, J W and Harwood, W A (2008). High-throughput Agrobacterium-mediated barley transformation. Plant Meth., 4(1): 22.

Bytebier, B; Deboeck, F and De Greve, H (1987). T-DNA organization in tumor cultures and transgenic plants of the monocotyledon Asparagus officinalis. Proc. Natl. Acad. Sci., 84(15): 5345-5349.

Casas, A M; Kononowicz, A K; Haan, T G; Zhang, L; Tomes, D T; Bressan, R A and Hasegawa, P M (1997). Transgenic sorghum plants obtained after microprojectile bombardment of immature inflorescences. In vitro Cell. Dev. Biol. Plant, 33(2): 92-100.

Christou, P and Ford, T L (1995). The impact of selection parameters on the phenotype and genotype of transgenic rice callus and plants. Transgenic Res., 4(1): 44-51.

Constantin, M; Nchu, W A; Godswill, N N; Wiendi, N M A; Wachjar, A and Frank, N E G (2015). Induction of oil palm (Elaeis guineensis Jacq. var. Tenera) callogenesis and somatic embryogenesis from young leaf explants. J. Appl. Biol. Biotechnol., 3(4): $4-10$

D'erfurth, I; Cosson, V; Eschstruth, A; Lucas, H; Kondorosi, A and Ratet, P (2003). Efficient transposition of the Tnt1 tobacco retrotransposon in the model legume Medicago truncatula. Plant J., 34(1): 95-106.

Fisher, D B (1968). Protein staining of ribboned epon sections for light microscopy. Histochemie, 16(1): 9296.

Gils, M (2017). A recessive pollination control system for wheat based on intein-mediated protein splicing. Split Inteins: Methods and Protocols, Methods in Molecular Biology (Mootz, H D ed.). Humana Press, New York, NY. p. 173-195.

Gonzalez, A; Jimenez, A; Vazquez, D; Davies, J E and Schindler, D (1978). Studies on the mode of action of hygromycin B, an inhibitor of translocation in eukaryotes. Biochim. Biophys.
Acta (BBA)-Nucleic Acids and Protein Synthesis, 521(2): 459-446.

Gutiérrez-E, M A; Luth, D and Moore, G A (1997). Factors affecting Agrobacterium-mediated transformation in citrus and production of sour orange (Citrus aurantium L.) plants expressing the coat protein gene of citrus tristeza virus. Plant Cell Rep., 16 (11): 745-753.

Haensch, K-T (2007). Influence of 2, 4-D and BAP on callus growth and the subsequent regeneration of somatic embryos in long-term cultures of Pelargonium $\mathrm{x}$ domesticum cv. Madame Layal. Electronic J. Biotechnol., 10 (1): 69-77.

Htwe, N N; Ling, H C; Zaman, F Q and Maziah, M (2014). Plant genetic transformation efficiency of selected Malaysian rice based on selectable marker gene (hptII). Pakistan J. Biol. Sci., 17(4): 472-471.

Ijaz, S; Anjum, N; Rana, I A and Khan, I A (2012). Optimization of minimal inhibitory dose of selective agent (Basta) for selection of transgenics in sugarcane. Mol. Plant Breed., 3(5): 50-56.

Itaya, A; Zheng, S and Simmonds, D (2018). Establishment of neomycin phosphotransferase II (nptII) selection for transformation of soybean somatic embryogenic cultures. In vitro Cell. Dev. Biol.-Plant, 54(2): 184-194.

Izawati, A M D; Masani, M Y A; Ismanizan, 1 and Parveez, G K A (2015). Evaluation on the effectiveness of 2-deoxyglucose-6-phosphate phosphatase $\left(D^{2} G^{\mathrm{R}} 1\right)$ gene as a selectable marker for oil palm (Elaeis guineensis Jacq.) embryogenic calli transformation mediated by Agrobacterium tumefaciens. Front. Plant Sci., 6: 727.

Kim, J B; Raemakers, C J J M; Jacobsen, E and Visser, R G F (2007). Efficient production of transgenic Alstroemeria plants by using Agrobacterium tumefaciens. Ann. Appl. Biol., 151(3): 401-412.

Kushairi, A; Singh, R and Abdullah, M (2017). The oil palm industry in Malaysia: thriving with transformative technologies. J. Oil Palm Res. Vol. 29(4): 431-439.

Li, L; Qu, R; De Kochko, A; Fauquet, C and Beachy, R N (1993). An improved rice transformation system using the biolistic method. Plant Cell Rep., 12(5): 250255 .

Li, Z; Upadhyaya, N M; Meena, S; Gibbs, A J and Waterhouse, P M (1997). Comparison of promoters and selectable marker genes for use in Indica rice transformation. Mol. Breeding, 3(1): 1-14. 
Li, M; Li, H; Jiang, H; Pan, X and Wu, G (2008). Establishment of an Agrobacterium-mediated cotyledon disc transformation method for Jatropha curcas. Plant Cell Tiss. Org., 92(2): 173-181.

Li, X; Fan, J; Gruber, J; Guan, R; Frentzen, $M$ and Zhu, L-H (2013). Efficient selection and evaluation of transgenic lines of Crambe abyssinica. Front. Plant Sci., 4: 162.

Liau, C H; You, S J; Prasad, V; Hsiao, H H; Lu, J C; Yang, N S and Chan, M T (2003). Agrobacterium tumefaciens-mediated transformation of an Oncidium orchid. Plant Cell Rep., 21(10): 993-998.

Majid, N A and Parveez, G K A (2007). Evaluation of green fluorescence protein (GFP) as a selectable marker for oil palm transformation via transient expression. Asia Pac. J. Mol. Biol. Biotech., 15(1): 1-8.

Majid, N A and Parveez, G K A (2016). Regeneration of transgenic oil palm carrying gfp gene used as a visual selectable marker. J. Oil Palm Res. Vol. 28(4): 415-430.

Mari, S; Engelmann, F; Chabrillange, N; Huet, C and Michaux-Ferrière, N (1995). Histo-cytological study of apices of coffee (Coffea racemosa and C. sessiliflora) in vitro plantlets during their cryopreservation using the encapsulation-dehydration technique. CryoLetters, 16(5): 289-298.

Masli, D I A; Kadir, A P G and Yunus, A M M (2009). Transformation of oil palm using Agrobacterium tumefaciens. J. Oil Palm Res. Vol. 21: 643-652.

Masli, D I A; Parveez, G K A and Ismail, I (2012). Optimisation of 2-deoxyglucose concentration for identifying the sensitivity level for oil palm embryogenic calli. J. Oil Palm Res. Vol. 24: 1296-1302.

Masura, S S; Tahir, N I; Rasid, O A; Ramli, U S; Othman, A; Masani, M Y A; Parveez, G K A and Kushairi, A (2017). Post-genomic technologies for the advancement of oil palm research. J. Oil Palm Res. Vol. 29(4): 469-486.

Meneses A; Flores D; Muñoz, M; Arrieta, G and Espinoza, A M (2005). Effect of 2, 4-D, hydric stress and light on indica rice (Oryza sativa) somatic embryogenesis. Rev. Biol. Trop., 53(3-4): 361-368.

Miki, B and McHugh, S (2004). Selectable marker genes in transgenic plants: applications, alternatives and biosafety. J. Biotechnol., 107(3): 193-232.

Milojević, J; Tubić, L; Nolić, V; Mitić, N; ĆalićDragosavac, D; Vinterhalter, B and ZdravkovićKorać, S (2012). Hygromycin promotes somatic embryogenesis in spinach. Plant Cell Tiss. Org., 109(3): 573-579.

Mitić, N; Nikolić, R; Ninković, S; Miljuš-Djukić, J and Nešković, M (2004). Agrobacterium-mediated transformation and plant regeneration of Triticum aestivum L. Biol. Plantarum, 48(2): 179-184.

Mitić, N; Vinterhalter, B; Ninković, S and Dodig, D (2014). The procedure providing enhanced Agrobacterium-mediated transformation of wheat. Biologia, 69(12): 1668-1677.

Murashige, T and Skoog, F (1962). A revised medium for rapid growth and bio assays with tobacco tissue cultures. Physiol. Plantarum, 15(3): 473-497.

Nurfahisza, A R; Rafiqah, M A; Masani, M Y A; Hanin, A N; Rasid, O A; Parveez, G K A and Ismail, I (2014). Molecular analysis of transgenic oil palm to detect the presence of transgenes. J. Oil Palm Res. Vol. 26(1): 96-103.

Nurfahisza, A R; Rafiqah, M A; Parveez, G K A and Rasid, O A (2016). Comparison of the effectiveness of Basta, bialaphos and glufosinate ammonium for selecting transformed oil palm tissues. J. Oil Palm Res. Vol. 28(3): 247-255.

Ong, A J; Marziah, M and Parveez, G K A (2000). Potential selective agents for orchid transformation. Asia-Pac. J. Mol. Biol. Biotechnol., 8(1): 85-93.

Park, S H; Rose, S C; Zapata, C; Srivatanakul, M and Smith, R H (1998). Cross-protection and selectable marker genes in plant transformation. In vitro Cell. Dev. Biol.-Plant, 34(2): 117-121.

Parveez, G K A; Chowdhury, M K U and Saleh, N M (1996). Determination of minimal inhibitory concentration of selection agents for oil palm (Elaeis guineensis Jacq.) transformation. Asia Pac. J. Mol. Biol. Biotechnol., 4(4): 219-228.

Parveez, G K A and Christou, P (1998). Biolisticmediated DNA delivery and isolation of transgenic oil palm (Elaeis guineensis Jacq.) embryogenic callus cultures. J. Oil Palm Res. Vol. 10(2): 29-38.

Parveez, G K A; Masri, M M; Zainal, A; Majid, N A; Yunus, A M M; Fadilah, H H; Rasid, O and Cheah, S-C (2000). Transgenic oil palm: Production and projection. Biochem. Soc. T., 28(6): 969-972.

Parveez, G K A; Majid, N A; Zainal, A and Rasid, O A (2007). Determination of minimal inhibitory concentration of selection agents for selecting transformed immature embryos of oil palm. Asia Pac. J. Mol. Biol. Biotechnol., 15(3): 133-146. 
Parveez, G K A and Majid, N A (2008). Factors affecting green fluorescence protein (GFP) gene expression in oil palm after microprojectile bombardment. J. Oil Palm Res. Vol. 20: 495-507.

Parveez, G K A; Bohari, B; Ayub, N A; Yunus, A M M; Rasid, O A; Hashim, A T; Ishak, Z; Manaf, M A A; Din, A K; York, G; Jo, Y B and Sinskey, A J (2008). Transformation of PHB and PHBV genes driven by maize ubiquitin promoter into oil palm for the production of biodegradable plastics. J. Oil Palm Res. Vol. 2: 77-86.

Parveez, G K A; Rasid, O A; Masani, M Y A and Sambanthamurthi, R (2015a). Biotechnology of oil palm: Strategies towards manipulation of lipid content and composition. Plant Cell Rep., 34(4): 533543.

Parveez, G K A; Bahariah, B; Ayub, N H; Masani, M Y A; Rasid, O A; Tarmizi, A H and Ishak, Z (2015b). Production of polyhydroxybutyrate in oil palm (Elaeis guineensis Jacq.) mediated by microprojectile bombardment of PHB biosynthesis genes into embryogenic calli. Front. Plant Sci., 6: 598.

Raja, N I; Bano, A; Rashid, H; Chaudhry, Z and Ilyas, N (2010). Improving Agrobacterium-mediated transformation protocol for integration of xa21 gene in wheat (Triticum aestivum L.). Pak. J. Bot., 42(5): 3613-3631.

Sambanthamurthi, R; Singh, R; Kadir, A P G; Abdullah, MO and Kushairi, A(2009). Opportunities for the oil palm via breeding and biotechnology. Breeding Plantation Tree Crops: Tropical Species (Jain, S $\mathrm{M}$ and Priyadarshan, $\mathrm{P}$ M eds.). Springer, New York. p. 377-421.

Sané, D; Aberlanc-Bertossi, F; Gassama-Dia, Y K; Sagna, M; Trouslot, M F; Duval, Y and Borgel, A (2006). Histocytological analysis of callogenesis and somatic embryogenesis from cell suspension of date palm (Pheonix dactylifera). Ann. Bot., 98(2): 301-308.

Shimamoto, K; Terada, R; Izawa, $\mathrm{T}$ and Fujimoto, H (1989). Fertile transgenic rice plants regenerated from transformed protoplasts. Nature, 338(6212): 274-276.

Sreeramanan, S; Maziah, M; Abdullah, M P; Rosli, N $\mathrm{M}$ and Xavier, R (2006). Potential selectable marker for genetic transformation in banana. Biotechnol., 5(2): 189-197.

Teixeira, J B; Sőndahl, M R; Nakamura, T and Kirby, E G (1995). Establishment of oil palm cell suspensions and plant regeneration. Plant Cell Tiss. Org., 40(2): 105-111.

Van Eck, J; Swartwood, K; Pidgeon, K and MaxsonStein, K (2017). Agrobacterium tumefaciens-mediated transformation of Setaria viridis. Genetics and Genomics of Setaria (Doust, A and Diao, X eds.). Springer, Cham. p. 343-356.

Velcheva, M; Faltin, Z; Vardi, A; Hanania, U; Eshdat, Y; Dgani, O; Sahar, N and Perl, A (2010). Aloe vera transformation: the role of Amberlite XAD-4 resin and antioxidants during selection and regeneration. In vitro Cell. Dev. Biol. Plant., 46(6): 477-484.

Wang, Z-Y; Bell, J and Lehmann, D (2004). Transgenic Russian wildrye (Psathyrostachys juncea) plants obtained by biolistic transformation of embryogenic suspension cell. Plant Cell Rep., 22(12): 903-909.

Yunus, A M M and Kadir, A P G (2008). Development of transformation vectors for the production of potentially high oleate transgenic oil palm. Electronic J. Biotechnol., 11(3): 23-31.

Yunus, A M M; Ho, C L and Parveez, G K A (2008). Construction of PHB and PHBV transformation vectors for bioplastics production in oil palm. J. Oil Palm Res. Vol. 2: 37-55. 